\title{
Assessing Intercultural Competence in Language Teacher Education
}

http://dx.doi.org/10.11606/1982-88372135144

\author{
Gabriela Marques-Schäfer ${ }^{1}$ \\ Danielle de Almeida Menezes ${ }^{2}$ \\ Sonia Zyngier ${ }^{3}$
}

\begin{abstract}
This paper investigates the concept(s) of intercultural competence held by undergraduate students from teacher education courses in English and German languages. To this end, first and fourth year undergraduates of English and German from a federal university in Rio de Janeiro answered two versions of a questionnaire designed to lead students to inductively formulate what they understood as intercultural competence and how they would help their future students develop this competence. Responses were submitted to content analysis and the four groups were compared. Results show that students of English and German who participated in this study hold different perspectives on intercultural competence and one of the reasons for that may be attributed to their educational background.
\end{abstract}

Keywords: Intercultural competence; pre-service programs; teacher education; English language students; German language students.

Resumo: O presente artigo investiga o(s) conceito(s) de competência intercultural de alunos de graduação de cursos de formação de professores em inglês e alemão. Nesse sentido, graduandos do primeiro e quarto ano de inglês e alemão de uma universidade federal do Rio de Janeiro responderam a duas versões de um questionário construído de tal forma que permitisse aos alunos formular indutivamente o que eles entendiam como competência intercultural e como eles poderiam auxiliar seus futuros alunos a desenvolver esta competência. As respostas foram submetidas à análise de conteúdo e os quatro grupos foram comparados. Os resultados mostram que os graduandos de inglês e alemão que participaram desta pesquisa apresentam perspectivas diversas sobre competência intercultural. Uma das razões pode ser atribuída à sua formação educacional.

\footnotetext{
${ }^{1}$ Universidade do Estado do Rio de Janeiro, Departamento de Letras Anglo-Germânicas, Rua São Francisco Xavier, 524, Rio de Janeiro, RJ, 20550-900, Brasil. E-mail: gabrielamarques@ yahoo.com.

${ }^{2}$ Universidade Federal do Rio de Janeiro, Faculdade de Educação, Avenida Pasteur, 250, Rio de Janeiro, RJ, 22290-240, Brasil. E-mail: danielle.menezes1981 @ gmail.com.

${ }^{3}$ Universidade Federal do Rio de Janeiro, Departamento de Letras Anglo-Germânicas, Avenida Brigadeiro Trompowsky, s/n, Rio de Janeiro, RJ, 21941-590, Brasil. E-mail: sonia.zyngier@gmail.com.
} 
Marques-Schäfer, G.; Menezes, D.A.; Zyngier, S. - Assessing Intercultural Competence

Palavras-chave: competência intercultural, programas de capacitação; formação de professores, alunos de inglês; alunos de alemão.

\section{Introduction}

The focus of language teaching has always been in constant change but the migratory processes in Europe in the 1960s and 1970s (PIEPHO 1974) have impacted the area more considerably. Conflicts and misunderstandings among people from various cultures have become more frequent and visible, and professionals from different areas such as psychology, sociology and applied linguistics have joined efforts to try to understand what these problems are (BREDELLA; HAACK 1988, BREDELLA 1988). In terms of language teaching, a consensus has developed among scholars that it cannot be dissociated from cultural awareness (KRAMSCH 1993, 1998; ALTMAYER 2004; KOREIK 2013). It is now widely accepted that learning a language requires intercultural competence, which extends the issue beyond linguistic knowledge. According to Deardorff (2006) the focus should be on "the ability to develop targeted knowledge, skills and attitudes that lead to visible behaviour and communication that are both effective and appropriate in intercultural interactions". This perspective poses a challenge to today's pre-service teacher education courses (KRUMM 2007), as not only are students expected to acquire the language targeted and develop critical thinking (FREIRE 1970), but they also need to become culturally self-aware and sensitive (HU 1999; RÖSLER 2012; STANKE 2014). The question now is how far these theoretical discussions are impacting the learning environments. In this direction, the present study investigates what undergraduates from two specific teacher education language and literature courses understand as intercultural competence and whether these theoretical discussions are reaching the students. To this purpose, responses to a questionnaire answered by first and fourth year undergraduates of English and German from a federal university in Rio de Janeiro, Brazil, are compared so as to observe how they identify and define what characterizes intercultural competence. Whereas first year students have had very little or no contact with theory at all, fourth graders have been exposed to theoretical texts throughout their studies. The study is carried out in the hope that the findings may show whether the theoretical discussions carried out in pre-service 
teaching have been affecting students' perceptions or whether they remain an abstraction.

\section{Theoretical background}

Before discussing the relevance of intercultural competence to language teacher education, we offer a review of some theoretical discussions on the notion of culture.

\subsection{The concept of culture}

It is quite difficult to define precisely what the term "culture" means as it involves a long history of usage. In addition, as Avruch (1998: 7) notes, "different political or ideological agendas [...], in one form or another, still resonate today". He shows how in the $19^{\text {th }}$ century, Matthew Arnold (1867, apud AVRUCH, 1998) defined it in relation to aesthetic production, distinguishing Culture (with capital "C") or "high culture" from popular culture, with a small "c". The ideal of a "civilized" society in detriment of more "primitive" ones was also sustained. Setting the ground for contemporary concepts, Avruch (1998: 6) cites British anthropologist Tyler, who argues that 'Culture [...] is that complex whole which includes knowledge, belief, art, morals, law, custom, and any other capabilities and habits acquired by man as a member of society.' However, only in the $20^{\text {th }} \mathrm{c}$ did anthropologists heed ethnographer Franz Boas and his followers, who held that high and low cultures should not be differentiated. Nowadays, according to Spencer-Oatey (2012), culture can be defined by six characteristics: 1) it is manifested at different layers of depth; 2) it affects behaviour and interpretations of behavior; 3 ) it can be differentiated from both universal human nature and unique individual personality; 4) it influences biological processes; 5) it is associated with social groups; 6) it is both an individual construct and a social construct; 7) it is always both socially and psychologically distributed in a group, and so the delineation of a culture's features will always be fuzzy; 8) it has both universal (etic) and distinctive (emic) elements; 9) it is learned; 10) it is subject to gradual change; 11) its various parts are all, to some degree, interrelated; 12) it is a descriptive not an evaluative concept. 
Marques-Schäfer, G.; Menezes, D.A.; Zyngier, S. - Assessing Intercultural Competence

Arguing in favor of a multicultural membership, Avruch states that:

Individuals are organized in many potentially different ways in a population, by many different (and cross-cutting) criteria: for example, by kinship into families or clans; by language, race, or creed into ethnic groups; by socio-economic characteristics into social classes; by geographical region into political interest groups; and by occupation or institutional memberships into unions, bureaucracies, industries, political parties, and militaries. The more complex and differentiated the social system, the more potential groups and institutions there are. And because each group of institution places individuals in different experiential worlds, and because culture derives in part from this experience, each of these groups and institutions can be a potential container for culture. Thus no population can be adequately characterized as a single culture or by a single cultural descriptor. As a corollary, the more complexly organized a population is on sociological grounds (class, region, ethnicity, and so on), the more complex will its cultural mappings appear (AVRUCH 1998: 17-18).

This discussion favours a view that culture is not a homogeneous or closed system. Rather, it is constructed as a heterogeneous network common to a certain social group who behaves and acts in reference to shared assumptions (cf. ALTMAYER 2006: 191).

The implications of such rationale to the teaching of Foreign Languages (FL) ${ }^{4}$ is that teachers and students must be aware that culture is a broad, flexible, complex and changeable concept that constitutes the way we think, feel and behave. Besides, it cannot be defined according to individual national groupings, as formerly crystallized in expressions such as English culture, German culture, Italian culture, French culture and so on. Regarding English, this fact is especially true and has been widely acknowledged since Kachru's contribution in 1986, when he defined the English language as in fact an umbrella term for diverse varieties, with local norms in different communities, both native and nonnative. According to Canagarajah (2014: 769), "globalization has progressed to the point where these [nonnative] communities are not immune from translocal influences [...]. Not only are they developing local uses of English, they are also increasingly interacting with other multilingual communities". Thus, speakers of the so-called nonnative communities of English do not use native speaker varieties when interacting. Conversely, "they develop another norm that

\footnotetext{
${ }^{4}$ We have opted for the expression Foreign Language as it has been traditionally used in Brazil to refer to languages different from Portuguese, which is spoken almost everywhere in the country. We are aware that competing expressions, such as Additional Language (cf. JORDÃO 2014), sound more welcome in the sense that languages other than the first add to the education of individuals and are part of their identity, not detached from it or struggling with it.
} 
Marques-Schäfer, G.; Menezes, D.A.; Zyngier, S. - Assessing Intercultural Competence

deviates from native speaker varieties" and the perspective of teaching in this scenario involves, in the author's words, "making students aware of this multilingual norm", which underlies the concept of International English (IE). Canagarajah (2014: 769) asserts that a recent perspective of IE conceives it "as a form of practice", since

multilingual speakers negotiate English according to their values, interests, and language repertoires in each interaction. What accounts for success is not the fact that they share a single norm (...), but that they adopt context- and interaction-specific communicative practices that help them achieve intelligibility.

The case of English is emblematic. Still, no language or culture is homogeneous. Assumptions and beliefs are generated from different perceptions and help build a complex picture which never determines what is true or false. The dichotomy truth/falsity does not hold as regards culture. According to Altmayer (2006: 55) the concept is not a unique empirical phenomenon. It is built from the discourse of different individuals. Therefore, in order to understand how culture is perceived, it is necessary to analyze the discourse of a number of individuals from a specific context. Collective responses can generate a broader outlook. It must be stressed, however, that research on culture is situated and must consider methods that account for social behavior at a certain place and time. In this sense, looking at discourse, or the way people communicate and act, may allow a more solid view on how a certain culture is perceived at a certain time and setting (ALTMAYER 2009).

\subsection{Intercultural learning of languages}

In the 1970s, when communicative competence became central to language learning, intercultural aspects were moved to the forefront of research on Foreign Language (FL) teaching. Besides the processes of globalization, migration and great mobility, those times also saw the FL classroom as a place to foster discussion on intercultural communication (HU 1999: 75). Institutions such as the Goethe-Institut or Robert Bosch Foundation among many others not only promoted intercultural dialogue, but also contributed to the understanding of communication and interpretation processes about general knowledge and notions of intercultural values. ${ }^{1}$

The tendency today in foreign language learning is towards both communicative competence and intercultural communicative competence. The latter should be 
Marques-Schäfer, G.; Menezes, D.A.; Zyngier, S. - Assessing Intercultural Competence

understood as the ability of an individual to master functional and communicative aspects of a certain language and, at the same time, to be able to exchange ideas, reflecting, relativizing ethnocentric perspectives and showing openness and interest when facing someone from a foreign culture (cf. BREDELLA 1988; PAULDRACH 1992; RÖSLER 2012).

According to Bechtel (2003: 55), an intercultural approach to teaching should have four main aims: (i) to learn the foreign culture; (ii) to reflect upon the student's culture and the culture of the target language country; (iii) to develop sensitivity to similarities and differences between the student's and the foreign culture; and (iv) to foster the exchange of perspectives.

What actually occurs is that when students reflect upon how another culture is perceived and evaluated, it is essential that the student realizes that his or her perception is relative and that pre-conceived evaluations should be avoided. In this sense, relativizing, interpreting, and understanding are actions to be promoted. In doing so, at the intersection between two or more cultures, a third one is built (cf. MARQUESSCHÄFER 2013: 246).

\subsection{Theoretical model}

Among the theoretical discussions and empirical studies that have been conducted along the last twenty years, one of the most influential model is Byram's (1997), where he describes five dimensions central to the success of intercultural communication: (i) savoirs, (ii) savoir comprendre, (iii) savoir apprendre/ faire, (iv) savoir être, (v) savoir s'engager.

According to Byram (1997), the concept savoirs refers to the knowledge someone must have about his and the other's cultures, and also the knowledge about processes of individual and social interaction; savoir comprendre is understood as the ability to understand and interpret cultures; savoir apprendre is related to the ability of learning something new about other cultures; savoir être is related to someone's attitude towards other cultures; finally, savoir s'engager is understood as some kind of critical awareness about the appearance, development and change of values, beliefs and social behaviors. 
Marques-Schäfer, G.; Menezes, D.A.; Zyngier, S. - Assessing Intercultural Competence

This model makes it clear that intercultural competence involves cognitive, affective, ethnic and behavioral levels, which are interconnected. Such aspects are linked to communicative, sociolinguistic and discursive competences in a FL setting in order to reach intercultural communicative competence, as Figure 1 illustrates:

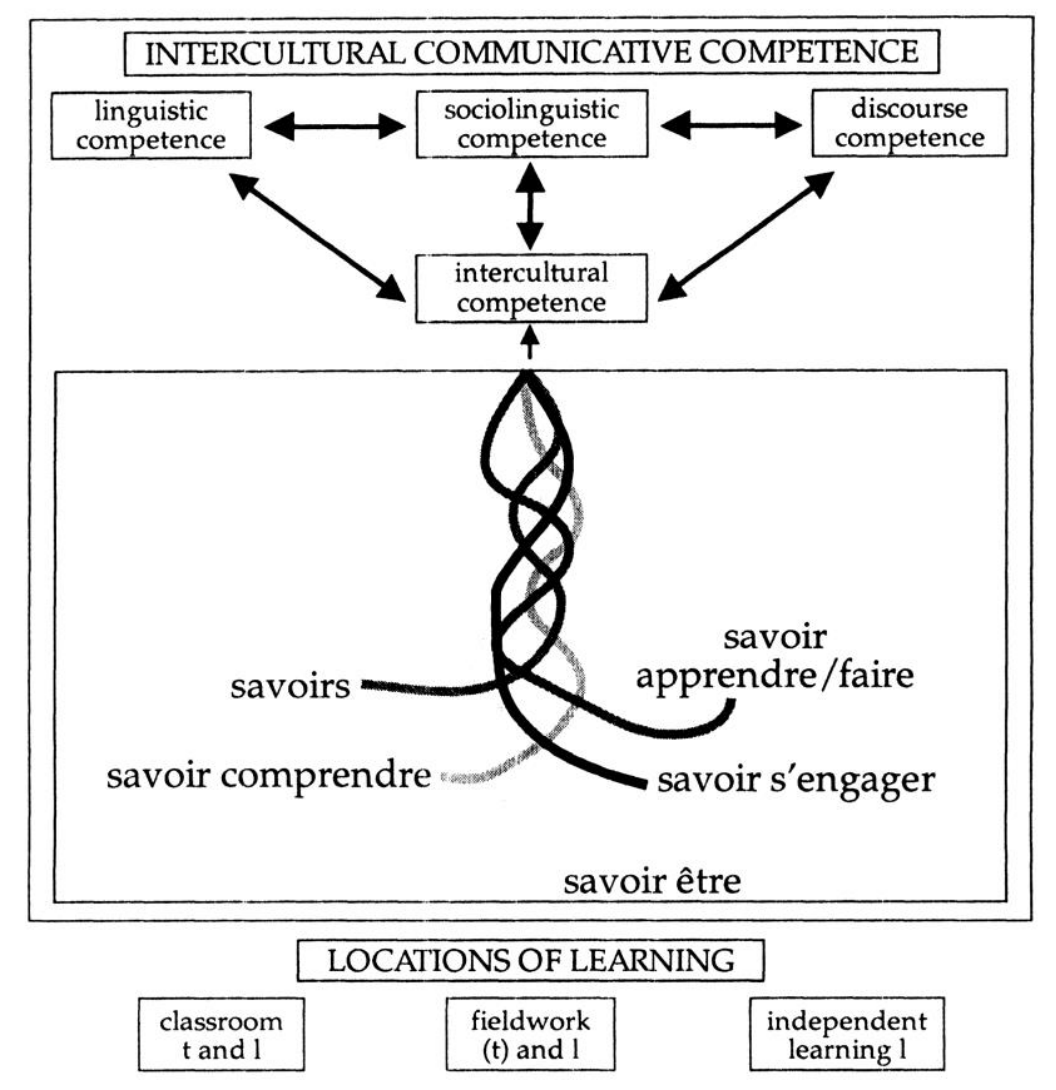

FIGURE 1

Intercultural communicative competence (BYRAM 1997: 73)

According to Byram (1997), intercultural competence can only be reached through three contexts: classroom, fieldwork and independent learning. Attitudes such as openness, curiosity and interest are a pre-requisite for promoting the meeting with others and the reflection about one's own opinion. A key concept in this respect is willingness to develop a relationship with someone or something new.

Finally, the central dimension of Byram's model is critical cultural awareness/ political education and it is linked to all the aspects previously described. This dimension demands a critical evaluation of perspectives, practices and products of one's own and of the other's culture. Throughout the process of learning, students should become "intercultural speaker[s]" and should be able to: 
Marques-Schäfer, G.; Menezes, D.A.; Zyngier, S. - Assessing Intercultural Competence

[...] negotiate a mode of communication and interaction which is satisfactory to themselves and the other and they are able to act as a mediator between people of different cultural origins. Their knowledge of another culture is linked to their language competence through their ability to use language appropriately - sociolinguistic and discourse connotations of the language. They also have a basis for acquiring new languages and cultural understandings as a consequence of the skills they have acquired in the first (BYRAM 1997: 71).

This theoretical model was the starting point for the analyses of the definitions our participants gave to intercultural competence. Based on this model, we arrived at four categories, detailed in Section 3.

\section{Methodology}

In order to find out how students of English and German conceptualize intercultural competence, and based on Byram's framework as described above, a questionnaire was devised as follows:

- The first part contained questions aimed at eliciting the participants' profile (e.g.: age, gender, whether beginner or advanced in language teacher education studies, level of English/ German, where and how the language was learned, among others).

- The second part presented an advert on a job available for flight attendants. Here participants were asked to write down what they considered to be intercultural competence needed for the job, and which strategies they would use to develop the skills they described in the previous question (see Annex).

The participants were 70 Brazilian university students of English (51 female and 18 male) and 32 students of German (26 female and 6 male). They were divided into four groups according to the language (English or German) and to their stage in learning (beginners or advanced in language teacher education).

Their responses to the first question, which described intercultural competence, were classified into categories. Initially based on Byram (1997), these categories were adapted according to the responses obtained from the participants, as follows: 
Marques-Schäfer, G.; Menezes, D.A.; Zyngier, S. - Assessing Intercultural Competence

\begin{tabular}{|l|l|}
\hline $\begin{array}{l}\text { Name and description of category } \\
\text { Intercultural competence depends on... }\end{array}$ & \multicolumn{1}{|c|}{ Example } \\
\hline $\begin{array}{l}\text { Affect (related to savoir être) } \rightarrow \text { empathy } \\
\text { and acceptance of others. }\end{array}$ & $\begin{array}{l}\text { E.g.: [2.1.12] - Empathy and (not legible) } \\
\text { to deal with different people and cultures. }\end{array}$ \\
\hline $\begin{array}{l}\text { Knowledge (related to savoirs) } \rightarrow \\
\text { knowledge about language, cultural } \\
\text { differences and facts related to the nations } \\
\text { where the language they are learning is } \\
\text { first or official }\end{array}$ & $\begin{array}{l}\text { E.g.: [1.1.27] - Cultural background is } \\
\text { necessary. [It's important to] know the } \\
\text { culture of certain countries in order to } \\
\text { deal with people, bearing in mind certain } \\
\text { details. }\end{array}$ \\
\hline $\begin{array}{l}\text { Capacity (related to savoir apprendre/ } \\
\text { faire). skill in dealing with foreigners. }\end{array}$ & $\begin{array}{l}\text { E.g.: [1.1.2] - In order to accomplish the } \\
\text { last item, the candidate must have the } \\
\text { capacity of dealing with people from } \\
\text { different cultures. (...) }\end{array}$ \\
\hline $\begin{array}{l}\text { Awareness (related to savoir s'engager) } \\
\text { awareness of the many implications } \\
\text { related to the contact with cultures diverse } \\
\text { from their own, avoiding prejudicial } \\
\text { behavior. }\end{array}$ & $\begin{array}{l}\text { E.g.: [1.2.2] The person who wants to } \\
\text { accomplish the last item needs to know } \\
\text { how to deal with culture shock, know } \\
\text { how to deal with difference, in a way that } \\
\text { prejudicial views are neither conceived } \\
\text { nor tolerated. }\end{array}$ \\
\hline
\end{tabular}

Figure 2

Categories obtained from responses to Question 1

The second question yielded seven categories, as follows:

\begin{tabular}{|l|l|}
\hline \multicolumn{1}{|c|}{$\begin{array}{c}\text { Name and description of category } \\
\text { Possible ways of developing } \\
\text { intercultural competence: }\end{array}$} & \multicolumn{1}{|c|}{ Example } \\
\hline $\begin{array}{l}\text { Transmit cultural facts } \rightarrow \text { teaching } \\
\text { cultural facts deductively }\end{array}$ & $\begin{array}{l}\text { E.g.: [2.1.1] - Introduce events, habits } \\
\text { and characteristics from the countries that } \\
\text { speak the target language (...) }\end{array}$ \\
\hline $\begin{array}{l}\text { Introduce different discourses } \\
\text { helping students access texts (written, } \\
\text { visual and oral) from different cultures }\end{array}$ & $\begin{array}{l}\text { E.g.: [1.1.17] - Introduce new cultures to } \\
\text { the student, by means of songs, series, } \\
\text { films (...) and other activities in the } \\
\text { classrooms that allow people understand } \\
\text { different cultures. }\end{array}$ \\
\hline $\begin{array}{l}\text { Promote linguistic activities } \rightarrow \\
\text { exercising the different skills of the target } \\
\text { language }\end{array}$ & $\begin{array}{l}\text { E.g.: [2.2.1] - (...) If I became a language } \\
\text { teacher, I would propose the daily } \\
\text { exercise of active (writing and speaking) } \\
\text { and passive (listening and reading) skills } \\
\text { of the language. }\end{array}$ \\
\hline $\begin{array}{l}\text { Arouse students' interest } \\
\text { encouraging and motivating students to } \\
\text { learn about cultural issues }\end{array}$ & $\begin{array}{l}\text { E.g,: [2.1.19] - [I would] try to arouse the } \\
\text { interest for the foreign culture, comparing } \\
\text { it with our daily life, showing songs from } \\
\text { the country, talking about religions, } \\
\text { habits, food and holidays. }\end{array}$ \\
\hline
\end{tabular}

Pandaemonium, São Paulo, v. 21, n. 35, set.-dez. 2018, p. 144-169 
Marques-Schäfer, G.; Menezes, D.A.; Zyngier, S. - Assessing Intercultural Competence

\begin{tabular}{|l|l|}
\hline $\begin{array}{l}\text { Stimulate research } \rightarrow \text { helping students } \\
\text { research by themselves. }\end{array}$ & $\begin{array}{l}\text { E.g.: [1.1.27] - (...) I would stimulate } \\
\text { cultural researches. }\end{array}$ \\
\hline $\begin{array}{l}\text { Raise awareness/ sensitize to } \\
\text { similarities and differences } \\
\text { sensitizing students to diversity. }\end{array}$ & $\begin{array}{l}\text { E.g.: [1.1.13] I would always stimulate } \\
\text { students to think like others, trying to put } \\
\text { themselves in the others'shoes. Making } \\
\text { them always question the differences, I } \\
\text { hope I can show them many possibilities. } \\
\text { Communication, real communication } \\
\text { with students is very important. }\end{array}$ \\
\hline $\begin{array}{l}\text { Stimulate interaction with people from } \\
\text { the target country/ countries } \\
\text { offering students opportunities to interact } \\
\text { with foreigners }\end{array}$ & $\begin{array}{l}\text { E.g.: [2.2.2] - (...) the student can (...) } \\
\text { keep in touch with native speakers. }\end{array}$ \\
\hline
\end{tabular}

FIGURE 3

Categories obtained from responses to Question 2

Adding to the qualitative categorization with the aim at seeing how this group of speakers verbalized concepts, we looked for strings of frequently co-occurring words that could be identified within the corpus. To this purpose, the responses were digitized and saved in 4 files (E 11, E 22, G 11, G 22). Known as 'clusters' (SCOTT 1997: 41), 'lexical bundles' (BIBER; CONRAD; REPPEN 1998: 993) or 'n-grams' (BANERJEE; PEDERSEN 2003), among other terms, strings of frequently occurring words can be quite powerful for text analysis of naturally-occurring language. These multiword units consist of a set of co-occurring words within a given window and reveal which units co-occur and in which order. There are no syntactic boundaries in this case. Once identified, the meaning and function of the strings were studied. As the corpus in this study was rather small, combinations of 3 adjacent words $(\mathrm{N}=3)$ were considered. Section 4 below details the results obtained.

\section{Analysis}

The nature of the instrument we used to generate the data, i.e. a questionnaire with open questions, allowed us to examine their content both qualitatively and quantitatively. First, we categorized the questions based on Byram's model and made room for variations from this model. We later searched for the frequency of co-occurring words in the corpus with the help of a concordance (Ant-Conc). Both approaches can be considered part of a methodological means of data prospection known as content 
Marques-Schäfer, G.; Menezes, D.A.; Zyngier, S. - Assessing Intercultural Competence

analysis (VAN PEER; HAKEMULDER; ZYNGIER 2012). According to Bardin (2011: 37), content analysis is broadly defined as a "group of techniques of analysis of communications", which allows different kinds of approaches. According to Van Peer, Hakemulder and Zyngier (2012: 92), through content analysis, communication is analyzed "by determining the frequencies of categories of thought, language, emotions symbols, etc., either previously defined or extracted in the course of analysis, and comparing these frequencies with respect to their potential meaning within a specific context". This methodological choice resulted from our need to differentiate the four groups investigated, and, at the same time, trace their characteristics.

\subsection{Analysis of the categories obtained}

In Question 1, we intended to find out what the participants understood as intercultural competence. In order to reach this aim inductively, they were asked to describe what the candidate for a position as flight attendant needed in order to be intercultural competent. Results are shown in the tables below:

TABLE 1

English_Beginners

\begin{tabular}{|l|c|c|}
\hline Category & Frequency in answers & Percentage (\%) \\
\hline 1 (Affect) & 17 & 21,25 \\
\hline 2 (Knowledge) & 32 & 40 \\
\hline 3 (Capacity) & 25 & 31,25 \\
\hline 4 (Awareness) & 5 & 6,25 \\
\hline 5 (Failed to understand) & 1 & 1,25 \\
\hline TOTAL & $\mathbf{8 0}$ & $\mathbf{1 0 0}$ \\
\hline
\end{tabular}

${ }^{5}$ Free translation of: "conjunto de técnicas de análise das comunicações”.

Pandaemonium, São Paulo, v. 21, n. 35, set.-dez. 2018, p. 144-169 
Marques-Schäfer, G.; Menezes, D.A.; Zyngier, S. - Assessing Intercultural Competence

TABLE 2

English__Advanced

\begin{tabular}{|l|c|c|}
\hline Category & Frequency in answers & Percentage (\%) \\
\hline 1 (Affect) & 6 & 14,65 \\
\hline 2 (Knowledge) & 16 & 39 \\
\hline 3 (Capacity) & 16 & 7,35 \\
\hline 4 (Awareness) & 3 & $\mathbf{1 0 0}$ \\
\hline TOTAL & $\mathbf{4 1}$ & \\
\hline
\end{tabular}

TABLE 3

German_Beginners

\begin{tabular}{|l|c|c|}
\hline Category & Frequency in answers & Percentage (\%) \\
\hline 1 (Affect) & 12 & 32,4 \\
\hline 2 (Knowledge) & 13 & 35,1 \\
\hline 3 (Capacity) & 8 & 21,65 \\
\hline 4 (Awareness) & 4 & 10,85 \\
\hline TOTAL & $\mathbf{3 7}$ & $\mathbf{1 0 0}$ \\
\hline
\end{tabular}

TABLE 4

German_Advanced

\begin{tabular}{|l|c|c|}
\hline Category & Frequency in answers & Percentage (\%) \\
\hline 1 (Affect) & 3 & 18,75 \\
\hline 2 (Knowledge) & 8 & 50 \\
\hline 3 (Capacity) & 3 & 18,75 \\
\hline 4 (Awareness) & 2 & 12,5 \\
\hline TOTAL & $\mathbf{1 6}$ & $\mathbf{1 0 0}$ \\
\hline
\end{tabular}

When comparing Tables 1, 2, 3 and 4, we notice that, as regards the category Affect, the German students (Tables 3 and 4) seem to value this aspect more than the English participants (Tables 1 and 2). It is interesting to notice that affect is reduced in both advanced groups (Tables 2 and 4: $21.25 \rightarrow 14.65 ; 32.4 \rightarrow$ 18.75), which may indicate that as they progress in their studies, they notice that the development of intercultural competence requires more than empathy. 
Marques-Schäfer, G.; Menezes, D.A.; Zyngier, S. - Assessing Intercultural Competence

As far as knowledge is concerned, this category is much valued by the four groups. However there is little difference between beginners and advanced English students (Tables 1 and 2: 39/40) and a huge difference from German participants (Tables 3 and 4: 35.1/50). This result may have been influenced by the background knowledge students bring to university in relation to the languages they study. On the one hand, students of English seem to start university more sensitized to the language and to some cultures where English is a mother tongue. This may happen due to fact that, in our society, exposure to television shows and songs in English, for instance, is frequent. On the other hand, students of German start graduation with little sensitization to the foreign culture and no background knowledge. As they reach more advanced levels, they realize this gap, which might lead them to overvalue aspects such as cultural facts or language issues.

As regards capacity, this variable is more valued by English students than by Germans (Tables 1 and 2: $31.25 \rightarrow$ 39; Tables 3 and 4: $21.65 \rightarrow 18.75$ ). With the advanced German group, it decreases. Again, this may have resulted from the more regular exposition English language participants have in their daily life than the opportunities students of German have. Besides, the awareness that English is far from being a homogeneous language and that different communities have their own accents and their own cultural values/habits may have also influenced this result. Reversely, German students still seem to associate culture to nation and to present a stereotypical view of what being German means. In addition, according to Tables 3 and 4, awareness increases for both English and German groups. However, the rates are higher for both beginners and advanced German groups. This might be an effect of pedagogical intervention and investments by the DAAD which promotes language courses conducted by native speakers (GTA Program and visiting lectures/ teachers) and cultural events such as film presentation followed by discussion, guest lectures on specific topics. As mentioned above, as students of English have more exposure to the language and recognition of different speaking communities, they might not have mentioned "awareness" as much as students of German did because it may be something they already take for granted.

As this investigation involves pre-service teachers, in Question 2 we considered important to ask them about the strategies they would use to develop the features described in the previous question. The following tables show the results: 
Marques-Schäfer, G.; Menezes, D.A.; Zyngier, S. - Assessing Intercultural Competence

TABLE 5

English__Beginners

\begin{tabular}{|l|c|c|}
\hline Category & Frequency & Percentage (\%) \\
\hline 1 (Transmit cultural facts) & 6 & 9,2 \\
\hline 2 (Introduce different discourses) & 23 & 35,5 \\
\hline 3 (Promote linguistic activities) & 7 & 10,7 \\
\hline 4 (Arouse students' interest) & 4 & 6,2 \\
\hline 5 (Stimulate research ) & 4 & 6,2 \\
\hline $\begin{array}{l}\text { 6) (Raise awareness / sensitize to similarities } \\
\text { and differences) }\end{array}$ & 9 & 13,8 \\
\hline $\begin{array}{l}\text { 7) (Stimulate interaction with people from } \\
\text { the target country/countries) }\end{array}$ & 6 & 9,2 \\
\hline 8) (No answer / other) & 6 & 9,2 \\
\hline TOTAL & $\mathbf{6 5}$ & $\mathbf{1 0 0}$ \\
\hline
\end{tabular}

TABLE 6

English_Advanced

\begin{tabular}{|l|c|c|}
\hline Category & Frequency & Percentage (\%) \\
\hline 1 (Transmit cultural facts) & 2 & 5,7 \\
\hline 2 (Introduce different discourses) & 12 & 34,3 \\
\hline 3 (Promote linguistic activities) & 6 & 17,2 \\
\hline 4 (Arouse students' interest) & 1 & 2,8 \\
\hline 5 (Stimulate research ) & 2 & 5,7 \\
\hline $\begin{array}{l}\text { 6) (Raise awareness / sensitize to similarities } \\
\text { and differences) }\end{array}$ & 12 & 34,3 \\
\hline $\begin{array}{l}\text { 7) (Stimulate interaction with people from } \\
\text { the target country/countries) }\end{array}$ & - & - \\
\hline TOTAL & $\mathbf{3 5}$ & $\mathbf{1 0 0}$ \\
\hline
\end{tabular}


Marques-Schäfer, G.; Menezes, D.A.; Zyngier, S. - Assessing Intercultural Competence

TABLE 7

German_Beginners

\begin{tabular}{|l|c|c|}
\hline Category & Frequency & Percentage (\%) \\
\hline 1 (Transmit cultural facts) & 14 & 43,8 \\
\hline 2 (Introduce different discourses) & 2 & 6,25 \\
\hline 3 (Promote linguistic activities) & 4 & 12,5 \\
\hline 4 (Arouse students' interest) & 7 & 21,9 \\
\hline 5 (Stimulate research ) & 3 & 9,3 \\
\hline $\begin{array}{l}\text { 6) (Raise awareness / sensitize to similarities } \\
\text { and differences) }\end{array}$ & 2 & 6,25 \\
\hline $\begin{array}{l}\text { 7) (Stimulate interaction with people from } \\
\text { the target country/countries) }\end{array}$ & - & $\mathbf{1 0 0}$ \\
\hline TOTAL & $\mathbf{3 2}$ & \\
\hline
\end{tabular}

TABLE 8

German_Advanced

\begin{tabular}{|l|c|c|}
\hline Category & Frequency & Percentage (\%) \\
\hline 1 (Transmit cultural facts) & 2 & 12,5 \\
\hline 2 (Introduce different discourses) & 5 & 31,25 \\
\hline 3 (Promote linguistic activities) & 4 & 25 \\
\hline 4 (Arouse students' interest) & 2 & 12,5 \\
\hline 5 (Stimulate research ) & - & 12,5 \\
\hline $\begin{array}{l}\text { 6) (Raise awareness / sensitize to similarities } \\
\text { and differences) }\end{array}$ & 2 & 6,25 \\
\hline $\begin{array}{l}\text { 7) (Stimulate interaction with people from } \\
\text { the target country/countries) }\end{array}$ & 1 & $\mathbf{1 0 0}$ \\
\hline TOTAL & $\mathbf{1 6}$ & \\
\hline
\end{tabular}

As far as strategies are involved, transmitting cultural facts is highly valued by German beginners (Table 7), but there is noticeable decrease when it comes to advanced students (Table 8: $48.8 \rightarrow 12.5$ ). Students of English do not focus on this strategy (Tables 5 and $6: 9.2 \rightarrow 5.7$ ) and tend to give preference to more language-oriented strategies. This difference may indicate that students of English tend to be stimulated to think about teaching strategies from the moment they begin their undergraduate studies, perhaps due to the fact that most of their instructors/lecturers/professors of English and English Didactics come from the field of Applied Linguistics and their intersections with Education. German instructors in this area, however, have a more literatureoriented background. Second, students of English in this institution are required to 
Marques-Schäfer, G.; Menezes, D.A.; Zyngier, S. - Assessing Intercultural Competence

study in detail official documents [such as the National Curricular Parameters (1998), National Curricular Orientations (2006) and National Common Curricular Basis (2015)], which are meant to guide the teaching of FL in regular schools, and adopt a socio-interactionist view of learning (JOHNSON 2009) that conflicts with a transmission model (SCARLETT; Ponte; Singh 2009). The same does not apply to students of German.

In addition, English students do show a preference for different discourses (Tables 5 and 6: $35.5 \rightarrow 34.3$ ), whereas the students of German start off with very little emphasis on this strategy, but increase dramatically (Tables 7 and 8: 6.25 $\rightarrow 31.25$ ) coming close to the rate obtained by the former group. These figures can find an explanation in the fact that students of English are already sensitised to World Englishes when they enter university, while students of German begin their studies thinking of a Culture (with capital $\mathrm{C}$ and preceded by an indefinite article, in the singular) that can be transmitted through the language. As they progress in their studies, they realise that discourses differ and that transmitting cultural facts is not a strategy that will promote intercultural competence. As far as emphasis on linguistic activity is concerned, there is a slight increase within the English group (Tables 5 and 6: $10.7 \rightarrow 17.2$ ) whereas the increase is greater within the German group (Tables 7 and 8: 12.5 $\rightarrow 25$ ). We believe this result is also an effect of the interventions described above.

It is interesting to note that the four groups do not emphasize arouse students' interest and this strategy is even lower with the English students, decreasing as they progress to advanced stages. Students seem to lack awareness that learning how to be intercultural competent requires initially an awareness of the self. It is the first skill a person needs so as to be ready to perceive differences. In this sense, this finding is in consonance with the emphasis on knowledge and less on affect.

According to the data obtained, the more passive posture of the students in relation to learning is reflected on their mention of learning by research. The groups do not seem to value this category, which rated low in the four groups. It even decreases with the students of English and disappears in the German group. This indicates that students still expect to be tutored rather than seek knowledge by themselves. They adopt a much more comfortable position, one that in a way clashes with awareness. This leads us to question whether their mentioning awareness as a necessary skill is something they are merely repeating from the theory they learn or if they actually practice it. 
Marques-Schäfer, G.; Menezes, D.A.; Zyngier, S. - Assessing Intercultural Competence

Another interesting finding refers to the category raising awareness. It seems to be valued by the more advanced groups, perhaps indicating that they have learned the lesson, but not assimilated the practice as something natural. Theory does not seem to have been internalized as intercultural competence remains on the level of the abstract.

As regards interacting with people from the target countries, the numbers are low and disappear with English advanced students. English students have access to varieties of English in their coursebook. It has been a tendency with coursebook writers to value varieties instead of relying on a model. With students of German, varieties are not an issue. Even though they exist in Brazil, including some dialects no longer spoken in Germany (for instance, Pomerano in Espírito Santo State), students of German in Rio are not made aware of them. They tend to see German as a homogeneous language. In their everyday life they have little contact - if any -- with speakers of German. There may be some students who have already learned some German in independent courses (either Goethe-Institut or Bauhaus) but these are a privileged few. Even in these courses, varieties are not targeted. It is only when they start their studies at the University that they find out about the language varieties of Germany, Switzerland, Austria, Lichtenstein and the north of Italy.

All in all, the participants in this study do not seem to see the need to interact with other cultures in order to acquire intercultural competence, which is paradoxical. What we have found is that these students are learning the theory but not living through it.

\subsection{Corpus analysis}

Once the responses were digitized, they were read by the concordancer. As the number of participants is rather small, we decided to use the tool only to help us see, within each corpus, the most frequent strings in each group and set them in order so that we could compare them. We also decided not to break into 4 groups as that would reduce the data even further. Table 9 shows what resulted from the comparison between the two major groups (English and German): 
Marques-Schäfer, G.; Menezes, D.A.; Zyngier, S. - Assessing Intercultural Competence

TABLE 9

All English-German compared

\begin{tabular}{|c|c|c|c|c|c|}
\hline \multicolumn{3}{|c|}{ ENGLISH-ALL } & \multicolumn{3}{|c|}{ GERMAN-ALL $^{6}$} \\
\hline \multicolumn{3}{|c|}{$\begin{array}{l}\text { \#Total No. of N-Gram Types: } 91 \\
\text { \#Total No. of N-Gram Tokens: } 297\end{array}$} & \multicolumn{3}{|c|}{$\begin{array}{l}\text { \#Total No. of N-Gram Types: } 27 \\
\text { \#Total No. of N-Gram Tokens: } 56\end{array}$} \\
\hline \multicolumn{3}{|c|}{ Order Frequency } & \multicolumn{3}{|c|}{ Order Frequency } \\
\hline 1 & 10 & with people of & 1 & 3 & the culture of \\
\hline 2 & 9 & the capacity of & 2 & 3 & of other country \\
\hline 3 & 9 & know to deal with & 3 & 2 & the culture of \\
\hline 4 & 8 & the candidate must & 4 & 2 & the culture and \\
\hline 5 & 7 & that the students & 5 & 2 & the differences between \\
\hline 6 & 6 & the different cultures & 6 & 2 & more and more \\
\hline 7 & 6 & with the passengers & 7 & 2 & such as the \\
\hline 8 & 6 & of different cultures & 8 & 2 & culture of the countries \\
\hline 9 & 6 & and respect the & 9 & 2 & culture and history \\
\hline 10 & 6 & deal with people & 10 & 2 & cultures and being \\
\hline 11 & 6 & so that the & 11 & 2 & of the German language \\
\hline 12 & 6 & people of different & 12 & 2 & of different nationalities \\
\hline 13 & 6 & classroom & 13 & 2 & of diverse cultures \\
\hline 14 & 5 & the diverse cultures & 14 & 2 & of origin and \\
\hline 15 & 5 & in a friendly way & 15 & 2 & of another language \\
\hline 16 & 5 & of other cultures & 16 & 2 & cultural differences and \\
\hline 17 & 5 & interacting with the & 17 & 2 & and the culture \\
\hline 18 & 5 & the passengers of & 18 & 2 & and history of \\
\hline 19 & 5 & passengers in a way & 19 & 2 & in relation to the \\
\hline 20 & 4 & the cultural differences & 20 & 2 & between the cultures \\
\hline 21 & 4 & of different countries & 21 & 2 & speakers of language \\
\hline 22 & 4 & of other countries & 22 & 2 & history of others \\
\hline 23 & 4 & of communicating & 23 & 2 & the habits of \\
\hline 24 & 4 & different cultures and & 24 & 2 & spoken countries of \\
\hline 25 & 4 & the candidate needs & 25 & 2 & by cultural differences \\
\hline 26 & 4 & the students to & 26 & 2 & about other cultures \\
\hline 27 & 4 & by means of & 27 & 2 & an intercultural competence \\
\hline 28 & 3 & with the differences & & & \\
\hline 29 & 3 & with the students & & & \\
\hline 30 & 3 & with other cultures & & & \\
\hline 31 & 3 & knowing other cultures & & & \\
\hline 32 & 3 & knowledge of different & & & \\
\hline 33 & 3 & cultures to & & & \\
\hline 34 & 3 & of interacting with & & & \\
\hline 35 & 3 & teaching the language & & & \\
\hline 36 & 3 & interacting with people & & & \\
\hline 37 & 3 & the candidate & & & \\
\hline
\end{tabular}

${ }^{6}$ The N-grams were in Portuguese.

Pandaemonium, São Paulo, v. 21, n. 35, set.-dez. 2018, p. 144-169 
Marques-Schäfer, G.; Menezes, D.A.; Zyngier, S. - Assessing Intercultural Competence

\begin{tabular}{|lll|l|}
\hline 38 & 3 & deal with the & \\
39 & 3 & languages and cultures & \\
40 & 3 & other cultures and & \\
41 & 3 & respecting the differences & \\
42 & 3 & being a person & \\
43 & 3 & a different culture & \\
\hline
\end{tabular}

What immediately draws our attention when comparing the most frequent strings of the two major groups is that the linguistic choices of English group seem to focus more on "people" (people, candidate, students, passengers) and "difference" (different cultures, people of different, diverse cultures etc.) than the German students. The latter, on the other hand, seem to be mostly concerned with "culture" itself (the culture of, the culture and, the culture of the countries, culture and history etc.). This result reinforces our previous findings that students of German relate intercultural competence to a notion of a homogeneous foreign culture, which they should learn. For these students of English, however, "culture" is more plural and individualized. This explains their emphasis on "differences" and "cultures". The theoretical discussions of homogeneous or varieties of language influence the production of didactic materials. As students of German rely on the course book as one of their main sources of contact with the target culture, which is not the case with students of English, they tend to be more sensitized specifically to concepts and tasks aiming at promoting intercultural competence. This possibly explains why this phrase is found only in the answers of the students of German.

\section{Final remarks}

The findings above allow us to state that, even though the participants come from the same university and are being educated to become teachers, their instruction seems to be based on different perspectives when it comes to the understanding of intercultural competence. We explain the differences between the two major groups based on contextual differences:

(1) Though official documents, such as the National Curricular Parameters (1998) and the National Curricular Guidelines (2006), suggest that any language can be taught in regular schools, most schools in Brazil still offer 
Marques-Schäfer, G.; Menezes, D.A.; Zyngier, S. - Assessing Intercultural Competence

English first and foremost. German, on the other hand, is only taught in bilingual schools of German-Portuguese or in independent courses;

(2) German educators in Brazil, irrespective of their nationality, tend to follow the theoretical framework adopted in Germany. Most English teacher educators, on the other hand, come from universities working in the intersection between Applied Linguistics and Education and tend to accept variations and globalization;

(3) English can be found everywhere in day-to-day interactions. The exposure to songs, TV shows, brand names, and other sources of contact with English is thus naturalized in the Brazilian setting; speakers tend to accept terms like "delivery", "shopping malls", "parking", "sale", etc. as part of their everyday vocabulary. The same does not apply to German;

(4) As a consequence of items 1 and 3, most students of English start university with some knowledge of the language, whereas for most students of German it is the first time they are exposed to the language.

This contextual difference regarding the two groups certainly leads Brazilian university students of German to favor acquiring cultural knowledge and language skills and allows students of English to focus their attention rather on interpersonal abilities and in classroom strategies, as evidenced by the data.

We could also notice some change when beginners and advanced students of each language are compared. This result indicates that their years as undergraduates influence their perceptions. Nevertheless, the education offered is far from being consensual, since advanced students of both groups presented considerably different perspectives.

In relation to Affect, we observed that, irrespective of the language, it decreases with advanced students. With the data we have, we are unable to explain this aspect. More studies need to be carried out to help clarify this issue.

We hope this pilot study may throw some light on how pre-service teachers see intercultural competence and how they position themselves. As a natural continuation of this study, we intend to analyze the participants' choice of language when they express their opinions, such as what kinds of processes (material, mental, verbal or relational) (cf. HALLIDAY 1994) are most frequent in each group and if they position 
Marques-Schäfer, G.; Menezes, D.A.; Zyngier, S. - Assessing Intercultural Competence

themselves as agents. Only then will we be in a better position to see more clearly how theory has been affecting the pre-service teachers.

\section{References}

AltMAYeR, Claus. Kultur als Hypertext. Zu Theorie und Praxis der Kulturwissenschaft im Fach Deutsch als Fremdsprache. München: Iudicium, 2004.

ALTMAYER, Claus. Landeskunde als Kulturwissenschaft. Ein Forschungsprogramm. Jahrbuch Deutsch als Fremdsprache 32, p. 181-199, 2006.

ALTMAYER, Claus. Instrumente für die empirische Erforschung kultureller Lernprozesse im Kontext von Deutsch als Fremdsprache. In: HU, A.; BYRAM, M. (Org.). Interkulturelle Kompetenz und fremdsprachliches Lernen. Modelle, Empirie, Evaluation. Tübingen: Narr, 2009. p. 123-138.

AvruCH, Kevin. Culture and Conflict Resolution. Washington DC: United States Institute of Peace Press, 1998.

BanerJee, Satanjeev; Pedersen, Ted. The design, implementation, and use of the Ngram Statistics Package. In: Proceedings of the Fourth International Conference on Intelligent Text Processing and Computational Linguistics, Mexico City, 2003. p 370381.

BARDin, Lawrence. Análise de Conteúdo. São Paulo: Edições 70, 2011.

BIBER, Douglas. CONRAD, Susan; REPPEN, Randi. Corpus Linguistics: Investigating Language Structure and Use. Cambridge: CUP, 1998.

BECHTEL, Mark. Interkulturelles Lernen beim Sprachenlernen im Tandem. Eine diskursanalytische Untersuchung. Tübingen: Narr, 2003.

BREDELLA, Lothar. How Is Intercultural Understanding Possible? In: Bredella, Lothar; HAACK, Dietmar (Org.). Perceptions and misperceptions: the United States and Germany. Studies in intercultural understanding. Tübingen: Narr, 1988. p. 1-25.

Bredella, Lothar; HAACK, Dietmar. (Org.). Perceptions and misperceptions: the United States and Germany. Studies in intercultural understanding. Tübingen: Narr, 1988.

BYRAM, Michael. Teaching and Assessing Intercultural Communicative Competence. Clevedon: Multilingual Matters, 1997.

CANAGARAJAH, Suresh. In Search of a New Paradigm for Teaching English as an International Language. TESOL Journal, v. 5, n. 4, p. 767-785, dez. 2014.

CONSElHo DA EUROPA. Quadro Europeu Comum de Referência para as Línguas. Aprendizagem, ensino, avaliação. Porto: Edições ASA, 2001.

DEARDORFF, Darla K. Identification and Assessment of Intercultural Competence as a Student Outcome of Internationalization at Institutions of Higher Education in the United States. Journal of Studies in International Education, v. 10, n. 3, p. 241-266, 2006.

FreIRE, Paulo. Pedagogia do Oprimido. Rio de Janeiro: Paz e Terra, 1970.

Halliday, Michael A. K. An Introduction to Functional Grammar. 2. ed. London: Arnold, 1994.

Hu, Adelheid. Interkulturelles Lernen. Eine Auseinandersetzung mit der Kritik an einem umstrittenen Konzept. Zeitschrift für Fremdsprachenforschung, v. 10, n. 2, p. 277-303, 1999.

JOHNSON, Karen. Second Language teacher education: a socio-cultural perspective. USA: Routledge, 2009. 
Marques-Schäfer, G.; Menezes, D.A.; Zyngier, S. - Assessing Intercultural Competence

KACHRU, Braj. The alchemy of English: The spread, functions and models of non-native Englishes. Oxford, England: Pergamon, 1986.

Koreik, Ulrich. Landeskunde. In: Oomen-Welke, Ingelore.; Ahrenholz, Bernt. (Org.). Deutsch als Fremdsprache. Baltmannsweiler: Schneider Verlag Hohengehren, 2013. p. 14781483.

KRAMSCH, Claire. Language and Culture. Oxford: Oxford University Press, 1998.

KRAMSCH, Claire. Context and Culture in Language Teaching. Oxford: Oxford University Press, 1993.

KRUMM, Hans-Jürgen. Curriculare Aspekte des interkulturellen Lernens und der interkulturellen Kommunikation. In: BAUSCH, Karl-Richard; CHRIST, Herbert; KRUMM, Hans-Jürgen. (Org.): Handbuch Fremdsprachenunterricht. 5. ed. Tübingen: A. Francke, 2007. p. 138-144.

MARQUES-SCHÄFER, Gabriela. Deutsch lernen online. Eine Analyse interkultureller Interaktionen in Chat. Tübingen: Narr, 2013.

MEC/SEF. Parâmetros curriculares nacionais: terceiro e quarto ciclos do Ensino Fundamental - Língua Estrangeira. Brasília: MEC/SEF, 1998.

MEC/SEF. Conhecimentos de Línguas Estrangeiras. In: Orientações Curriculares para o Ensino Médio - Volume 1: Linguagens, Códigos e suas Tecnologias. Brasília: MEC/SEF, 2006.

MEC/SEF. Base Nacional Comum Curricular. Brasília, 2016.

PAULDRACH, Andreas. Eine unendliche Geschichte. Anmerkungen zur Situation der Landeskunde in den 90er Jahren. Fremdsprache Deutsch. Zeitschrift für die Prazis des Deutschunterrichts, v. 6. München: Klett International, 1992. p. 4-15.

PIEPHO, Hans-Eberhard. Kommunikative Kompetenz als übergeordnetes Lernziel im Englischunterricht. Dornburg-Frickhofen: Frankonius, 1974.

RÖSLER, Dietmar. Deutsch als Fremdsprache. Stuttgart/Weimar: Metzler, 2012.

SCARlett, W. George; Ponte, IrIS Chin; Singh, JAY P. Approaches to Behavior and Classroom Management: Integrating Discipline and Care. UK: SAGE Publications Ltd., 2009.

ScotT, MichaEL. WordSmith Tools version 2. Oxford: Oxford University, 1997.

STANKE, Roberta. Landeskunde na formação universitária do professor de alemão como língua estrangeira. In: BOLACIO, Ebal; FUNK, Hermann (Org.). Kulturdidaktik im Unterricht Deutsch als Fremdsprache. Deutsch lehren und lernen - kooperativ-kompetent-kreativ. Rio de Janeiro: APA, 2014. p. 201-218.

Van Peer, Willie; HaKemulder, Frank; Zyngier, Sonia. Scientific Methods for the Humanities. Amsterdam: John Benjamins, 2012. 


\section{CULTURAL ISSUES AND LANGUAGE TEACHER EDUCATION}

Dear undergraduate, the following questionnaire is part of a research under development by Language Teacher Educators from the Federal University of Rio de Janeiro and the State University of Rio de Janeiro. Your participation is essential for the development of this research. It may take you 15 minutes to fulfill it. The questionnaire is anonymous and your authorization to use the data will be given at the moment you hand it in with the answers. In case you are interested to know more about the research, at the end of the questionnaire you will find our contact e-mails.

Thank you for your participation!

\section{Part 1 - Profile}

1. Age: ( ) 16-18; ( ) $19-21 ; \quad$ ( ) $22-24 ; \quad$ ( ) $25-27 ; \quad$ ( ) $28-30 ; \quad$ ( ) 31 or more

2. You consider yourself: ( ) Woman ( ) Man

3. You are:

( ) In the first year of your graduation course

( ) At the end of your Language Teacher Education course

4. You are studying to be a teacher of: ( ) English ( ) German

5. How much did you know about the language above mentioned before entering the university?

( ) Nothing. I started studying the language when I entered the university.

( ) A little. Though I could read a little, I was unable to speak or write well.

( ) Well. I started the course being able to understand and use the foreign language.

( ) A lot. I started the course being able to understand and use the foreign language proficiently.

6. Did you systematically study the target language before graduation?

( ) Yes ( ) No - In case you answer NO, skip to Question 9.

\footnotetext{
${ }^{7}$ Students of German were given a version of this questionnaire with the advertisement in the German language. 
Marques-Schäfer, G.; Menezes, D.A.; Zyngier, S. - Assessing Intercultural Competence

7. Where / How did you study the target language?
( ) At private language schools
( ) At school
( ) At school and at private language schools
( ) With a private tutor

8. How long have you studied the target language before entering the university?
( ) less than a year
( ) from one to two years
( ) from three to four years
( ) from five to six years
( ) seven years or more

( ) I am not sure, because I started and stopped studying the language many times or I didn't have regular classes at school.

9. Do you (still) study the target language at any language school to help you catch up with the classes at the university?

( ) Yes ( ) No

10. Have you ever been to a country in which the first language is the one you study?

( ) Yes ( ) No 


\title{
Part 2 - Reading
}

\section{Read the advertisement below and answer the questions that follow:}

(Full version of the ad:

https://www.be-lufthansa.com/fileadmin/fm-

lufthansabe/PDFs/B9 1_Flugbegleiter/LH_D Flugbegleiter.pdf)

\section{Flight Attendant (m/f) with Lufthansa}

\begin{abstract}
A job as a Flight Attendant remains one of the most fascinating and interesting professions.
However, it is a much more demanding occupation than one may think: interacting with passengers in a continuously friendly, competent, and responsible way, following service expectations, and calmly coping with even the most difficult situations.

Those who display such qualities will be rewarded with an exciting job in which one can meet fascinating people of all nationalities and languages, work with a nice team of colleagues, and have the opportunity to get to know foreign countries and cultures.
\end{abstract}

\section{Requirements}

- Minimum age: 18 years old

- Completed school education

- Minimum height: $1.60 \mathrm{~m}$ and an appropriate weight

- Visual acuity between +/- 5 diopters

- Passport without restrictions that is valid for at least 12 months

- No visible tattoos or piercings*

- Good swimming skills

- Fluent in German and English

- Willingness to do shiftwork and work abroad

- Intercultural competence 
Marques-Schäfer, G.; Menezes, D.A.; Zyngier, S. - Assessing Intercultural Competence

1. Describe the skills the candidate for the position as a flight attendant needs to show in order to fulfill the last requirement above.

2. As Foreign Language pre-service teacher, which strategies would you use to make your students develop the skills you described in the previous question?

Thank you for your contribution! 